\title{
GENOTOXIC EVALUATION OF THE EFFECT OF Thuya occidentalys TINCTURES
}

\author{
VALSA, J. O. and FELZENSZWALB, I. \\ Departamento de Biofísica e Biometria, Instituto de Biologia Roberto Alcantara Gomes, Universidade do Estado do \\ Rio de Janeiro, CEP 20551-030, Rio de Janeiro, RJ, Brazil \\ Correspondence to: Israel Felzenszwalb, Departamento de Biofísica e Biometria, Instituto de Biologia Roberto \\ Alcantara Gomes, Universidade do Estado do Rio de Janeiro, Av. 28 de Setembro, 87, fds., CEP 20551-030, \\ Rio de Janeiro, RJ, Brazil, e-mail: felzen@uerj.br \\ Received May 19, 1999 - Accepted May 10, 2000 - Distributed May 31, 2001
}

\begin{abstract}
Three tinctures samples from extracts of the popular medicinal plant Thuya occidentalis were tested in vitro through two short term tests for measuring the activity of genotoxic chemicals. Using the Salmonella/mammalian-microsome (Mutatest) assay and the SOS-chromotest (induction of $\beta$-galactosidase in Escherichia coli), none of the extract was effective in inducing mutagenesis or $\beta$-galactosidase synthesis (as an indicator of general and early sign of DNA damage), even with metabolization.
\end{abstract}

Key words: Thuya occidentalis, Salmonella/mammalian-microsome assay, SOS-chromotest, popular medicine.

\section{RESUMO}

\section{Avaliação genotóxica do efeito de tinturas de Thuya occidentalys}

Três amostras de tinturas de extratos da planta Thuya occidentalis, utilizada em medicina popular, foram testadas in vitro por meio de dois testes rápidos para medida da atividade genotóxica de químicos. Utilizando o teste de Ames (Mutateste) e o SOS-cromoteste (indução de $\beta$-galactosidase em Escherichia coli), verificouse que nenhum dos extratos foi efetivo na indução de mutagênese ou na síntese de $\beta$-galactosidase (como o indicador de um sinal geral e precoce de lesão no DNA), mesmo com metabolização.

Palavras-chave: Thuya occidentalis, teste de Ames, SOS-cromoteste, medicina popular.

\section{INTRODUCTION}

The pharmacologic activity of plants and herbs in teas, syrups, cataplasm and tinctures is well established in popular medicine. However, some of them have deleterious effects, for example, some plants, taken as infusion by the population of developing countries have shown mutagenic, toxic and carcinogenic activities (Evans, 1991; Roeder, 1995). Among the plants used in Brazil as popular medicine, there is one, Thuya occidentalis which is recomended as expectorant, diuretic, anti-helmintic, stimulating and in rheumatism treatment. It acts in the renal ephitelium and has a toxic action in bladder muscles (Balbach, 1957; Van der Bergh, 1982). It is used in the treatment of cystitis and prostatic hypertrophy in senile and in the urinary incontinence in women. As tincture, it is popularly used as an abortive, as an agent for cauterization in papilomas treatment and wart candilomas (Dr. P. Maldonado, personal communication). In the present study, we used two reliable, standardized and accepted short-term tests developed by Ames et al. (1975) and Quillardet et al. (1982), testing three different samples of Thuya occidentalis tinctures.

\section{MATERIAL AND METHODS}

The Salmonella typhimurium and Escherichia coli strains used in this work, are described elsewhere (Ames et al., 1975; Felzenszwalb \& 
Alcantara Gomes, 1982; Valsa et al., 1990) and maintained according to the revised methods of Maron \& Ames (1983) and Quillardet et al. (1982).

To evaluate the lethal effect of Thuya occidentalis samples, $2 \mathrm{ml}$ of E.coli $\mathrm{K} 12$ AB1157 overnight cultures in Luria broth (LB) medium (Miller, 1972) were incubated with $50 \mu$ of test solution (diluted $1: 10$ ) at $37^{\circ} \mathrm{C}$, for $25 \mathrm{~min}$, with shaking. After that, $100 \mu \mathrm{l}$ of properly diluted treated cultures were spread onto LB plates (LB medium solidified with $1.5 \%$ agar-agar). The colonies were counted after $24-36 \mathrm{~h}$ of incubation at $37^{\circ} \mathrm{C}$ and the surviving fraction was calculated as mentioned elsewhere (Felzenszwalb \& Alcantara Gomes, 1982).

In the Mutatest assays, the experimental procedure adopted was the pre-incubation method (Maron \& Ames, 1983) slightly modified (Valsa et al., 1990).

In the SOS-chromotest assays, logarithmicphase cells of E.coli PQ37 in LB medium were diluted 10 times in culture medium and $600 \mu \mathrm{l}$ was incubated with $20 \mu \mathrm{l}$ of different dilutions of Thuya occidentalis samples or controls (positive and negative) for $2 \mathrm{~h}$ at $37^{\circ} \mathrm{C}$. Then the $\beta$-galactosidase and alkaline-phosphatase activities were measured by colorimetric assay. The alkaline-phosphatase synthesis is constitutive and is used as representative of the action of the drug tested in general protein synthesis. The experiments were carried out in triplicate and the results presented are the average mean of two independent assays. The standard deviation did not exceed $20 \%$.

Preliminary tests of concentrated tinctures showed a toxic effect for both $S$. typhimurium and $E$. coli strains (data not shown). All experiments were then performed with dilutions of the concentrated tinctures in deionised and destiled water.
Ethanolic extracts of Thuya occidentalis were kindly supplied by Dr. Ribeiro de Miranda (Arte de Curar - Homeopatia, Três Rios, RJ), and we analysed three different tinctures samples, called sample 1,2 and 3.

\section{RESULTS AND DISCUSSION}

The absorption spectra of the three solutions were constructed between 300 and $600 \mathrm{~nm}$, using Incibras Spectrophotometer MF200 UVVIS and showed to be the same with a maximum of absorption in $350 \mathrm{~nm}$ (data not shown). The determination of the absorption spectra was important as there are some preparations of Thuya tinctures that are composed of mixtures, instead of Thuya occidentalis alone (Dr. R. de Miranda, personal communication).

There is a strong correlation between the ability of chemicals to be genotoxic to bacteria and their mutagenic and tumour initiating properties in mammals (Purchase, 1982; Venitt et al., 1984). The capacity of a chemical to induce bacterial death, mutagenesis or SOS system expression is widely used to detect potential carcinogenic effects (Quillardet \& Hofnung, 1988).

Although an inactivation effect was observed for the three tested samples (Table 1), their mutagenic capacity, assayed by the Ames method, was not higher than the background level (revertant mutants present in culture medium without treatment) even with metabolic activation (+S9) (S9 mix: Maltox ${ }^{\mathrm{TM}}$ ), as shown in Table 2. Difference in survival is in agreement with the absorption of the three samples, where sample 1 showed to be less concentrated (data not shown). The results obtained with SOS-chromotest confirm the absence of SOS functions induction effect (Table 3) and the toxicity of concentrated solutions, measured by alkaline-phosphatase activities.

TABLE 1

Survival fractions of Escherichia coli K12 AB1157 cells treated with ethanolic extracts of Thuya occidentalis.

\begin{tabular}{|l|c|}
\hline \multicolumn{1}{|c|}{ Thuya occidentalis (dilution 1/10) } & $\begin{array}{c}\text { Survival fraction (number of viable cells after 25 min treatment/number of } \\
\text { viable cells at time zero) }\end{array}$ \\
\hline Culture medium & 1.3 \\
\hline Sample 1 & $2.2 \times 10^{-1}$ \\
\hline Sample 2 & $2.2 \times 10^{-2}$ \\
\hline Sample 3 & $2.1 \times 10^{-2}$ \\
\hline
\end{tabular}


TABLE 2

Salmonella/mammalian-microsome assay with Thuya occidentalis.

\begin{tabular}{|c|c|c|c|c|c|c|c|c|c|c|c|c|}
\hline \multirow[t]{3}{*}{ Compound } & \multirow[t]{3}{*}{ Dilution } & \multirow{3}{*}{$\begin{array}{c}\text { Volume } \\
(\mu \mathrm{l})\end{array}$} & \multicolumn{10}{|c|}{ Revertant colonies per plate } \\
\hline & & & \multicolumn{2}{|c|}{ TA97 } & \multicolumn{2}{|c|}{ TA98 } & \multicolumn{2}{|c|}{ TA100 } & \multicolumn{2}{|c|}{ TA1535 } & \multicolumn{2}{|c|}{ TA102 } \\
\hline & & & $-\mathbf{S 9}$ & $+\mathrm{S9}$ & $-\mathbf{S 9}$ & $+\mathrm{S9}$ & -S9 & +S9 & $-\mathbf{S 9}$ & $+\mathrm{S9}$ & $-\mathbf{S 9}$ & $+\mathrm{S9}$ \\
\hline $\begin{array}{l}\text { Culture } \\
\text { medium }\end{array}$ & - & 50 & 108 & 219 & 33 & 58 & 161 & 198 & 24 & 19 & 327 & 412 \\
\hline \multirow[t]{5}{*}{ SAMPLE 1} & $1 / 10$ & 50 & 101 & 216 & 18 & 48 & 159 & 174 & 13 & 15 & 287 & 372 \\
\hline & & 100 & 87 & 206 & 25 & 48 & 202 & 187 & 22 & 16 & 302 & 272 \\
\hline & $1 / 100$ & 100 & 94 & 180 & 21 & 43 & 183 & 184 & 13 & 16 & 281 & 392 \\
\hline & $1 / 1000$ & 50 & 75 & 212 & 25 & 50 & 192 & 220 & 17 & 17 & 287 & 352 \\
\hline & & 100 & 85 & 220 & 27 & 45 & 208 & 197 & 16 & 19 & 339 & 388 \\
\hline \multirow[t]{5}{*}{ SAMPLE 2} & $1 / 10$ & 50 & 90 & 215 & 39 & 53 & 163 & 159 & 17 & 18 & 324 & 371 \\
\hline & & 100 & 79 & 193 & 34 & 46 & 197 & 208 & 23 & 20 & 320 & 429 \\
\hline & $1 / 100$ & 100 & 95 & 217 & 36 & 54 & 146 & 187 & 16 & 20 & 329 & 412 \\
\hline & $1 / 1000$ & 50 & 91 & 217 & 32 & 48 & 159 & 171 & 24 & 18 & 295 & 437 \\
\hline & & 100 & 89 & 199 & 34 & 46 & 155 & 187 & 17 & 20 & 323 & 411 \\
\hline \multirow[t]{5}{*}{ SAMPLE 3} & $1 / 10$ & 50 & 117 & 208 & 27 & 49 & 164 & 167 & 19 & 21 & 293 & 387 \\
\hline & & 100 & 115 & 202 & 34 & 52 & 184 & 177 & 22 & 19 & 308 & 415 \\
\hline & $1 / 100$ & 100 & 121 & 203 & 33 & 53 & 169 & 157 & 26 & 16 & 308 & 377 \\
\hline & $1 / 1000$ & 50 & 117 & 199 & 31 & 56 & 163 & 179 & 26 & 19 & 264 & 416 \\
\hline & & 100 & 110 & 197 & 31 & 55 & 164 & 166 & 28 & 20 & 289 & 408 \\
\hline $\begin{array}{l}\text { 4NQO } \\
(0,5 \mu \mathrm{g})\end{array}$ & - & 50 & 537 & - & 231 & - & 5,052 & - & 104 & - & 591 & - \\
\hline $\begin{array}{l}2-\mathrm{AF} \\
(10 \mu \mathrm{g})\end{array}$ & - & 50 & - & 1,776 & - & 4,060 & - & 3,508 & - & 101 & - & 648 \\
\hline
\end{tabular}

Observation: non-diluted samples were tested as described in Maron \& Ames (1983) with the spot-test and showed to be toxic (data not shown). Positive controls: 4-nitroquinoline-N-oxide and 2-aminofluorene (Sigma Chemicals).

TABLE 3

SOS-Chromotest with Thuya occidentalis ethanolic tinctures with or without metabolic activation.

\begin{tabular}{|c|c|c|c|c|c|c|c|c|c|}
\hline \multirow[t]{2}{*}{$\begin{array}{l}\text { T. occidentalis } \\
\text { ethanolic tinctures } \\
\text { (amount } 20 \mu \mathrm{l} \text { ) }\end{array}$} & \multirow[t]{2}{*}{ Dilutions } & \multicolumn{2}{|c|}{$\begin{array}{c}\text { Phosphatase } \\
\text { units }\end{array}$} & \multicolumn{2}{|c|}{$\begin{array}{c}\beta \text {-GAL } \\
\text { units }\end{array}$} & \multicolumn{2}{|c|}{ R $\frac{\beta \text {-GAL units }}{\text { Phosp. units }}$} & \multicolumn{2}{|c|}{$\begin{array}{c}\text { Induction } \\
\text { factor } \\
I=\frac{R(c)}{R(0)}\end{array}$} \\
\hline & & -S9 & $+\mathrm{S9}$ & -S9 & $+\mathrm{S9}$ & -S9 & $+\mathrm{S} 9$ & -S9 & $+\mathrm{S9}$ \\
\hline \multirow[t]{7}{*}{ SAMPLE 1} & $2.5 \times 10^{-1}$ & 179 & 5.4 & 32.6 & 18.7 & 0.14 & 2.3 & 0.87 & 1 \\
\hline & $5 \times 10^{-1}$ & 183 & 4 & 27.3 & 15 & 0.11 & 2.5 & 0.68 & 1 \\
\hline & $1 \times 10^{-1}$ & 167 & 3.7 & 30.3 & 20 & 0.14 & 3.6 & 0.87 & 1.5 \\
\hline & $5 \times 10^{-2}$ & 180 & 3.6 & 28.6 & 19.4 & 0.12 & 3.5 & 0.75 & 1.5 \\
\hline & $1 \times 10^{-2}$ & 182 & 4.4 & 32 & 20 & 0.14 & 3.1 & 0.87 & 1.3 \\
\hline & $5 \times 10^{-3}$ & 179 & 4 & 31 & 19.2 & 0.13 & 3.2 & 0.81 & 1.3 \\
\hline & $1 \times 10^{-3}$ & 172 & 3.6 & 30.3 & 21.6 & 0.14 & 4 & 0.87 & 1.7 \\
\hline \multirow[t]{7}{*}{ SAMPLE 2} & $2.5 \times 10^{-1}$ & 112 & 4.8 & 19 & 26.8 & 0.20 & 3.9 & 0.95 & 1.6 \\
\hline & $5 \times 10^{-1}$ & 122 & 5.4 & 13 & 21.3 & 0.10 & 2.7 & 0.47 & 1.1 \\
\hline & $2 \times 10^{-1}$ & 110 & 6 & 20 & 26.5 & 0.20 & 3.1 & 0.95 & 1.3 \\
\hline & $5 \times 10^{-2}$ & 112 & 5 & 29 & 27.3 & 0.26 & 3.8 & 1.23 & 1.6 \\
\hline & $1 \times 10^{-2}$ & 110 & 4.1 & 18 & 28.7 & 0.17 & 4.9 & 0.80 & 2.1 \\
\hline & $5 \times 10^{-3}$ & 115 & 5 & 13 & 27 & 0.12 & 3.8 & 0.57 & 1.6 \\
\hline & $2 \times 10^{-3}$ & 120 & 3.2 & 15 & 26.4 & 0.13 & 5.8 & 0.60 & 2.5 \\
\hline \multirow[t]{2}{*}{ SAMPLE 3} & $2.5 \times 10^{-1}$ & 83 & 6.6 & 19 & 11 & 0.22 & 1.25 & 1.04 & 0.5 \\
\hline & $5 \times 10^{-1}$ & 84 & 4.4 & 20 & 10 & 0.25 & 1.73 & 1.19 & 0.7 \\
\hline
\end{tabular}


TABLE 3 (Continued)

\begin{tabular}{|c|c|c|c|c|c|c|c|c|c|}
\hline \multirow[t]{2}{*}{$\begin{array}{l}\text { T. occidentalis } \\
\text { ethanolic tinctures } \\
\text { (amount } 20 \mu \mathrm{l} \text { ) }\end{array}$} & \multirow[t]{2}{*}{ Dilutions } & \multicolumn{2}{|c|}{$\begin{array}{c}\text { Phosphatase } \\
\text { units }\end{array}$} & \multicolumn{2}{|c|}{$\begin{array}{c}\beta \text {-GAL } \\
\text { units }\end{array}$} & \multicolumn{2}{|c|}{ R $\frac{\beta \text {-GAL units }}{\text { Phosp. units }}$} & \multicolumn{2}{|c|}{$\begin{array}{c}\text { Induction } \\
\text { factor } \\
I=\frac{R(\mathbf{c})}{R(0)}\end{array}$} \\
\hline & & -S9 & $+\mathbf{S 9}$ & -S9 & +S9 & $-\mathbf{S 9}$ & $+\mathrm{S9}$ & $-S 9$ & $+\mathrm{S} 9$ \\
\hline & $1 \times 10^{-1}$ & 73 & 6.2 & 22 & 9.1 & 0.3 & 1.10 & 1.42 & 0.4 \\
\hline & $5 \times 10^{-2}$ & 72 & 6.6 & 17 & 9.3 & 0.24 & 1.00 & 1.14 & 0.4 \\
\hline & $1 \times 10^{-2}$ & 72 & 6.5 & 19 & 8.5 & 0.25 & 0.98 & 1.19 & 0.4 \\
\hline & $5 \times 10^{-3}$ & 73 & 7.2 & 19 & 9.3 & 0.26 & 0.96 & 1.20 & 0.4 \\
\hline & $2 \times 10^{-3}$ & 72 & 8.0 & 16 & 0.3 & 0.22 & 0.87 & 1.04 & 0.3 \\
\hline 4NQO (20 mg) & & 89 & - & 160 & - & 1.8 & - & 8.5 & - \\
\hline AFB1 (5 mg) & & - & 5.8 & - & 175 & - & 20 & - & 8.6 \\
\hline DMSO & & 179 & 6.3 & 32.6 & 19.2 & 0.14 & 2 & 0.75 & 0.8 \\
\hline Ethanol $95 \%$ & & 162 & 4.5 & 18 & 9.8 & 0.08 & 1.4 & 0.5 & 0.6 \\
\hline
\end{tabular}

Observations: (a) non-diluted samples were toxic; (b) it was used $20 \mu \mathrm{l}$ of samples (1,2 and 3) and controls (negative and positive) for incubation with $0.6 \mathrm{ml}$ of tester strain (E. coli PQ 37); DMSO (dimethyl sulfoxide - Merck); AFB1 Aflatoxin B1 (Sigma Chemical).

Presence of the activating mixtures has a slight inhibitory effect on protein synthesis which is reduced by a factor of about three in the two hours incubation period. In addition, the presence of phosphastes inhibits competitively the activity of alkaline phosphatase so that the ratio of $b$ galactosidase to alkaline phosphatase activities is increased by a factor of 13 in the presence of S9 mix (Dr. P. Quillardet, personal communication).

As natural products from flora and fauna are frequently used as medicaments (Gomes et al., 1996), we call attention to the control of such compounds since they may present genetic toxicity and moreover it is very important to check their cancer inducing potentiality, as measured by the capacity of activating SOS functions, in the form they are consumed by population.

Acknowledgments - We thank to P. R. Figueiredo Souto for excellent technical assistance. Research supported by UERJ/ $\mathrm{SR} 2, \mathrm{CNPq}$ and FAPERJ.

\section{REFERENCES}

AMES, B. N., McCANN, J. \& YAMASAKI, E., 1975, Methods for detecting carcinogens and mutagens with the Salmonella/mammalian-microsome mutagenicity test. Mutation Research, 31: 347-364.

BALBACH, A., 1957, A flora nacional na medicina doméstica, $12^{\text {nd }}$ ed. Ed. A Edificação do Lar, São Paulo, p. 58.

EVANS, W. C., 1991, Farmacognosia - trease-evans. $13^{\text {nd }}$ ed. Nueva Editorial Interamericana, S.A. México, 901p.

FELZENSZWALB, I. \& ALCANTARA GOMES, R., 1982, Reductone effect on UV-irradiated starved E. coli cells. Rev. Brasil. Genet., 1: 15-29.
GOMES, E. M., SOUTO, P. R. F. \& FELZENSZWALB, I., 1996, Sharrk-cartilage containing preparation protects cells against hydrogen peroxide induced damage and mutagenesis. Mutation Res., 367: 203-208.

MARON, D. M. \& AMES, B. N., 1983, Revised methods for the Salmonella mutagenicity test. Mutation Research, 113: $173-215$

MILLER, J. H., 1972, Experiments in molecular genetics. Cold Spring Harbor Laboratory. Cold Spring Harbor, NY.

PURCHASE, I. F. H., 1982, An appraisal of prediticve tests for carcinogenicity. Mutation Research, 99: 53-71.

QUILlARDET, P., HUISSMAN, O., D’ARI, R. \& HOFNUNG, M., 1982, SOS-chromotest, a direct assay of induction of an SOS function in E. coli K12 to measure genotoxicity. Proceedings National Academy of Science (USA), 79: 5971-5975.

QUILLARDET, P. \& HOFNUNG, M., 1988, The screening, diagnosis and evaluation of genotoxic agents with batteries of bacterial tests. Mutation Research, 205: 107-118.

ROEDER, E., 1995, Medicinal plants in Europe containing pyrrolidizine alkaloids. Pharmazie, 50: 83-98.

VALSA, J. O., FELZENSZWALB, I., CALDEIRA DE ARAÚJO, A. \& ALCANTARA GOMES, R., 1990, Genotoxic effect of a keto-aldehyde produced by thermal degradation of reducing sugars. Mutation Research, 232: 31-35.

Van der BERGH, M. E., 1982, Plantas medicinais da Amazonia: contribuição ao seu conhecimento sistemático. CNPq/PTU, Belém, p. 65.

VENITT, S., CROFTON-SLEIGH, C. \& FORSER, R., 1984, Bacterial mutation assays using reverse mutation, pp. 4598. In: Mutagenicity testing a practical approach. IRL Press Washington D.C. 